\title{
Estimates of genetic parameters in diallelic populations of cotton subjected to water stress
}

\author{
Walmir S. Vasconcelos ${ }^{1}$, Roseane C. dos Santos², Ubieli A. A. Vasconcelos ${ }^{3}$, José J. V. Cavalcanti \& \\ Francisco J. C. Farias ${ }^{2}$ \\ ${ }^{1}$ Universidade Estadual da Paraíba/Programa de Pós-Graduação em Ciências Agrarias. Campina Grande, PB, Brasil. E-mail: walmirsv@hotmail.com \\ (Corresponding author) - ORCID: 0000-0002-4159-6432 \\ ${ }^{2}$ Embrapa Algodão/Setor de Melhoramento. Campina Grande, PB, Brasil. E-mail: roseane.santos@embrapa.br - ORCID: 0000-0002-9039-946X; jaime. \\ cavalcanti@embrapa.br - ORCID: 0000-0002-7564-5562; francisco.farias@embrapa.br - ORCID: 0000-0002-7213-0694 \\ ${ }^{3}$ Universidade Federal de Viçosa/Departamento de Fitotecnia. Viçosa, MG, Brasil. E-mail: ubieli_araujo@hotmail.com - ORCID: 0000-0002-1319-9915
}

\begin{abstract}
The objective of this study was to estimate the general combining ability (GCA) and specific combining ability (SCA) of cotton genotypes subjected to water stress, based on fiber quality traits. Irrigated cotton plants were grown in the dry season in the Northeast region of Brazil and subjected to 23 days without irrigation at the beginning of the flowering stage. GCA and SCA analyses were based on the partial diallel model. Significant differences were found for GCA for all traits, with predominance of additive effects. The crossing between the genotypes FM-966 and CNPA-5M was the most promising hybrid combination, showing great potential for improvements in fiber quality in environments subjected to water stress, such as the Semiarid region of the Northeast of Brazil.
\end{abstract}

Key words: Gossypium hirsutum L., combining ability, drought tolerance

\section{Estimativa de parâmetros genéticos em população dialélica de algodoeiro submetida a estresse hídrico}

RESUMO: O objetivo deste estudo foi estimar a capacidade geral de combinação (CGC) e a capacidade específica de combinação (CEC) em genótipos de algodão submetidos ao estresse hídrico, baseados em características tecnológicas de fibras. Plantas de algodão foram cultivadas na estação seca, sob regime de irrigação, e sujeitas a 23 dias de supressão de água no início do florescimento. Análises das capacidades geral e específica de combinação foram realizadas com base no modelo dialélico parcial. Significância estatística foi detectada apenas para CGC, em todas as características, com predomínio de efeitos aditivos. O cruzamento entre os genótipos FM-966 e CNPA-5M foi a combinação híbrida mais proeminente, revelando grande potencial para melhoria da qualidade das fibras em ambientes sujeitos ao estresse hídrico, como o semiárido nordestino.

Palavras-chave: Gossypium hirsutum L., capacidade de combinação, tolerância à seca 


\section{INTRODUCTION}

Upland cotton (Gossypium hirsutum, L.) is one of the major commodities worldwide and has great value for textile and oil industries. Brazil is fifth largest cotton producing country, with a production of 1.5 million Mg of cotton lint, after India, China, the United States, and Pakistan (ABRAPA, 2018).

Cotton crops can be conducted with different managements, depending on the technological level adopted by the producer. High yields can be achieved with improved cultivars, adequate soil fertility, irrigation management, and pest and disease control. However, the occurrence of abiotic stresses during the reproductive stage, such as high temperature, salinity, and water stress, may negatively affect the plant yield (Dabbert \& Gore 2014, Rodrigues et al., 2018).

Most cultivars marketed in Brazil are not well-adapted to environments subjected to water stress. Several research institutions in Brazil have invested on the development of cultivars with wider environmental adaptation. For instance, the Empresa Brasileira de Pesquisa Agropecuária (Embrapa) leads a robust program focused on semiarid environments to identify promising lines, tolerant to water stress caused by irregularities and unavailability of water supply in the region.

Diallelic analyses are methodologies usually adopted by breeders to evaluated the inheritance of economically important traits and identify promising individuals. The diallel consists of a cross between parents, resulting in hybrid combinations that allow estimating general and specific combining abilities (Cruz et al., 2012).

The estimate of general combining ability (GCA) denotes the potential of each parent to generate favorable allelic combinations for a trait and is related to additive effects of the genes that control the trait.

The specific combining ability (SCA) denotes the effects of dominance and non-additive interactions of alleles, resulting from the complementation of alleles of the parents involved in a cross. The best hybrid combinations are those with the highest SCA estimates, with at least one parent with high GCA (Cruz et al., 2012).

Several studies on diallel analysis have focused on cotton fiber quality. Ng et al. (2014) evaluated five parents and found additive effects for micronaire, fiber length, elongation, strength, and uniformity. Imran et al. (2012) estimated GCA and SCA in a diallel scheme involving five parents and found differences between the hybrid combinations for fiber percentage, indicating the predominance of non-additive genes for this trait. Kumar et al. (2014) evaluated genetic effects and combining abilities in upland cotton and confirmed the predominance of additive genetic effects for all traits.

Zeng \& Pettigrew (2015) evaluated combining abilities and heritability in $\mathrm{F}_{2}$ cotton hybrids for yield and fiber traits at different planting dates within a growing season and found significant differences in GCA and nonsignificant differences in SCA for fiber traits, indicating predominance of additive genetic effects. Kothari et al. (2016) evaluated the combining ability in cotton genotypes to improve oil concentration and found significant differences in GCA and SCA for fiber traits, indicating presence of additive and non-additive genetic control.

Queiroz et al. (2017) evaluated genetic effects and general and specific combining abilities in upland cotton for fiber traits in the Semiarid region of Northeast of Brazil and reported significant genetic variability and predominance of additive effects for all traits. Vasconcelos et al. (2018) evaluated genetic effects and general and specific combining abilities in $\mathrm{F}_{1}$ cotton hybrids resistant to droughts and found predominance of additive effects for cotton seed yield, lint percentage, flowering, boll weight, and dominance effect for plant height; and that the hybrid combinations BRS-286 $\times$ CNPA-5M, BRS-RUBI $\times$ CNPA-5M, FM-966 $\times$ CNPA-5M, and BRS-286 $\times$ SERIDÓ had the best SCA and the highest mean values for most evaluated traits.

The objective of this work was to conduct a diallel analysis to estimate the GCA and SCA between parents and cotton hybrid combinations subjected to water stress, focusing on fiber quality traits.

\section{Material And Methods}

Twenty full-sib $\mathrm{F}_{1}$ hybrid combinations from a partial diallel cross were used. The cultivars used as parents were divided into two groups (Table 1): GI, formed by five cultivars with high fiber yield (Cia et al., 2014; Carvalho et al., 2015; Coutinho et al., 2015; Zonta et al., 2016); and GII, formed by four cultivars adapted to the Semiarid region of Northeast of Brazil, except CNPA-ITA-90, which is tolerant to water stress in the Cerrado region of Brazil (Freire et al., 1999; Vidal Neto \& Freire, 2013).

The experiments were carried out at the Embrapa-Cotton Experimental Field, in Barbalha, state of Ceará, Brazil ( $7^{\circ} 18^{\prime} 18^{\prime \prime} \mathrm{S}, 39^{\circ} 18^{\prime} 7^{\prime \prime} \mathrm{W}$, and altitude of $414 \mathrm{~m}$ ) during the dry seasons (July to December) of 2014 and 2015 . The average temperature during the experiments was $24.1^{\circ} \mathrm{C}$. The soil of

Table 1. Groups of cotton parents used in the partial diallel scheme

\begin{tabular}{|c|c|c|c|c|}
\hline Parent & Recommended region & Maturity & Fiber color & Main trait \\
\hline \multicolumn{5}{|l|}{ Group I: } \\
\hline 1. FMT-705 & Cerrado & Early-intermediate & White & High fiber yield \\
\hline 2. FM-966 & Cerrado & Early & White & High fiber yield \\
\hline 3. BRS-RUBI & Cerrado & Intermediate & Brown & High fiber yield \\
\hline 4. BRS-286 & Cerrado & Early-intermediate & White & High fiber yield \\
\hline 5. FMT-701 & Cerrado & Late & White & High fiber yield \\
\hline \multicolumn{5}{|l|}{ Group II: } \\
\hline 6. CNPA-ITA-90 & Cerrado & Late & White & Tolerance to water stress \\
\hline 7. CNPA-5M & Semiarid & Late & White & Tolerance to water stress \\
\hline 8. CNPA-7MH & Semiarid & Late & White & Tolerance to water stress \\
\hline 9. BRS-Seridó & Semiarid & Intermediate & White & Tolerance to water stress \\
\hline
\end{tabular}


the area was classified as Typic Udifluvent; fertilization was carried out based on the soil analysis, using $250 \mathrm{~kg} \mathrm{ha}^{-1}$ of monoammonium phosphate (MAP) at sowing, and $125 \mathrm{~kg} \mathrm{ha}^{-1}$ of urea divided into two applications, at 35 and 50 days after emergence (DAE).

The plants were subjected to 23 days without irrigation at the beginning of flowering, $42 \mathrm{DAE}$. The sprinkler irrigation was kept at a flow rate of $1.49 \mathrm{~m}^{3} \mathrm{~h}^{-1}$, based on previous tests conducted by Bezerra et al. (2010). The experimental plot consisted of two 5 -meter rows, spaced $0.90 \mathrm{~m}$ apart. The plants were spaced $0.14 \mathrm{~m}$ apart, totaling 70 plants per plot. The experiment was conducted in a randomized block design with 20 treatments and three repetitions.

The following variables were analyzed: fiber length (UHM; $\mathrm{mm}$ ); fiber uniformity (UNF; \%); short fiber index (SFI); strength (STR; gf tex ${ }^{-1}$ ); elongation (ELG; \%), micronaire (MIC), maturity index (MAT), and spinning index (CSP). These variables were evaluated at the Embrapa's Cotton and Fiber Technology Laboratory, located in Campina Grande, state of Paraíba, Brazil, in an HVI (Uster HVI 1000), using 20 bolls per plot as the standard sample.

Statistical-genetic analyses were performed using the GENES 6.1 program (Cruz, 2016). Analyses of variance (ANOVA) and clustering of means were carried out (Scott \&
Knott, 1974). The joint analysis was conducted considering the genotypes as fixed effects and years as random effects (Cruz et al., 2012).

A model of partial diallel analysis was adopted for genetic analysis, based on the Griffing IV Method (Griffing, 1956), adapted by Geraldi \& Miranda Filho (1988), to estimate the GCA effects of each parent and SCA effects of their hybrid combinations.

\section{Results AND Discussion}

The results of the joint analysis of variance (Table 2) showed significant differences between genotypes $(G)$ for all variables, indicating a high variability, which can be explored in breeding programs. Most traits presented no significant differences for years (Y), except UHM and MIC, indicating that the environmental conditions of the two years similarly contributed to the overall mean of the experiments. The $\mathrm{G} \times$ $Y$ interaction was significant for all variables, except SFI and MAT, indicating that the genotypes presented similar results in both years for these traits, and different results for the other traits.

The means of the fiber quality traits (Table 3 ) of the 20 cotton hybrid combinations subjected to water stress were clustered

Table 2. Joint analysis of variance for cotton fiber traits of $F_{1}$ cotton hybrids under water stress conditions

\begin{tabular}{|c|c|c|c|c|c|c|c|c|c|}
\hline \multirow{2}{*}{ SV } & \multirow{2}{*}{ DF } & \multicolumn{8}{|c|}{ Mean square } \\
\hline & & UHM & UNF & SFI & STR & ELG & MIC & MAT & CSP \\
\hline Block & 4 & 1.91 & 1.37 & 0.55 & 2.35 & 0.25 & 0.02 & 0.0005 & 368370.80 \\
\hline Genotype (G) & 19 & $15.75^{\star \star}$ & $6.14^{\star \star}$ & $8.04^{\star \star}$ & $33.48^{\star \star}$ & $1.47^{\star \star}$ & $0.63^{\star \star}$ & $0.0005^{\star \star}$ & $495213.65^{\star \star}$ \\
\hline Year $(Y)$ & 1 & $43.38^{* \star}$ & 0.01 & 0.22 & 2.34 & 1.24 & $2.85^{\star \star}$ & 0.0017 & 210899.52 \\
\hline$G \times Y^{\prime}$ & 19 & $2.48^{\star *}$ & $1.80^{\star \star}$ & 0.53 & $3.29 * *$ & $0.35^{\star \star}$ & $0.12^{\text {** }}$ & 0.0001 & $91029.55^{\star \star}$ \\
\hline Error & 76 & 0.64 & 0.85 & 0.32 & 1.36 & 0.12 & 0.02 & 0.0001 & 30665.52 \\
\hline & & $(\mathrm{mm})$ & \multicolumn{2}{|c|}{$(\%)$} & $\left(g f t e x^{-1}\right)$ & $(\%)$ & & $(\%)$ & \\
\hline Mean & & 28.78 & 84.13 & 7.97 & 28.60 & 5.01 & 4.85 & 0.88 & 2528.80 \\
\hline CV (\%) & & 2.78 & 1.09 & 7.18 & 4.08 & 6.99 & 3.27 & 0.77 & 6.92 \\
\hline
\end{tabular}

Table 3. Means of cotton fiber traits of $F_{1}$ cotton hybrids grown under water stress conditions

\begin{tabular}{|c|c|c|c|c|c|c|c|c|}
\hline \multirow[b]{2}{*}{ Hybrids } & \multicolumn{8}{|c|}{ Traits } \\
\hline & $\begin{array}{l}\text { UHM } \\
(\mathrm{mm})\end{array}$ & UNF & SFI & $\underset{\left(g \operatorname{ftex}^{-1}\right)}{\text { STR }}$ & $\begin{array}{l}\text { ELG } \\
(\%)\end{array}$ & MIC & $\begin{array}{l}\text { MAT } \\
(\%)\end{array}$ & CSP \\
\hline FMT-705 × CNPA-ITA-90 & $26.57 \mathrm{C}$ & $83.48 b$ & $8.59 b$ & $26.39 \mathrm{c}$ & $5.26 \mathrm{a}$ & $5.11 \mathrm{a}$ & $0.89 \mathrm{a}$ & $2334.39 \mathrm{e}$ \\
\hline FMT-705 × CNPA-5M & $29.28 b$ & $85.11 \mathrm{a}$ & $6.76 \mathrm{c}$ & $29.96 b$ & $6.04 \mathrm{a}$ & $4.90 \mathrm{~b}$ & $0.89 \mathrm{a}$ & $2625.79 b$ \\
\hline FMT-705 $\times$ CNPA-7MH & $29.17 b$ & $84.85 \mathrm{a}$ & $7.14 \mathrm{c}$ & $30.80 \mathrm{a}$ & $4.62 \mathrm{~b}$ & $5.20 \mathrm{a}$ & $0.89 \mathrm{a}$ & $2630.99 b$ \\
\hline FMT-705 × BRS-Seridó & $27.95 \mathrm{C}$ & $84.43 a$ & $7.84 \mathrm{c}$ & $28.60 \mathrm{~b}$ & $4.77 \mathrm{~b}$ & $5.24 a$ & $0.89 \mathrm{a}$ & $2384.82 \mathrm{~d}$ \\
\hline FM-966 × CNPA-ITA-90 & $29.05 b$ & $83.97 b$ & $7.70 \mathrm{c}$ & $28.44 b$ & $4.77 \mathrm{~b}$ & $4.52 \mathrm{C}$ & $0.87 \mathrm{~b}$ & $2558.32 \mathrm{c}$ \\
\hline FM-966 × CNPA-5M & $31.17 \mathrm{a}$ & $85.03 \mathrm{a}$ & $7.06 \mathrm{c}$ & $31.85 \mathrm{a}$ & $4.59 \mathrm{~b}$ & $4.53 \mathrm{c}$ & $0.87 \mathrm{~b}$ & $3039.56 \mathrm{a}$ \\
\hline FM-966 × CNPA-7MH & $29.43 b$ & $85.57 \mathrm{a}$ & $6.85 \mathrm{c}$ & $32.14 \mathrm{a}$ & $4.21 \mathrm{c}$ & $4.88 \mathrm{~b}$ & $0.89 \mathrm{a}$ & $2950.84 \mathrm{a}$ \\
\hline FM-966 × BRS-Seridó & $30.03 b$ & $85.99 \mathrm{a}$ & $6.93 \mathrm{c}$ & $29.49 b$ & $4.42 \mathrm{~b}$ & $5.35 a$ & $0.91 \mathrm{a}$ & $2680.16 \mathrm{~b}$ \\
\hline BRS-RUBI $\times$ CNPA-ITA-90 & $26.06 \mathrm{c}$ & $82.08 b$ & $10.71 \mathrm{a}$ & $23.80 d$ & $5.53 \mathrm{a}$ & $4.44 \mathrm{C}$ & $0.86 \mathrm{~b}$ & $2081.73 \mathrm{f}$ \\
\hline BRS-RUBI $\times$ CNPA-5M & $27.29 \mathrm{C}$ & $83.24 b$ & $8.86 \mathrm{~b}$ & $25.22 \mathrm{~d}$ & $5.47 \mathrm{a}$ & $4.88 \mathrm{~b}$ & $0.87 \mathrm{~b}$ & $2323.72 \mathrm{e}$ \\
\hline BRS-RUBI $\times$ CNPA-7MH & $26.52 \mathrm{c}$ & $82.98 b$ & $9.40 \mathrm{~b}$ & $24.93 d$ & $5.74 \mathrm{a}$ & $4.29 \mathrm{~d}$ & $0.87 \mathrm{~b}$ & $2097.87 \mathrm{f}$ \\
\hline BRS-RUBI $\times$ BRS-Seridó & $26.02 \mathrm{C}$ & $82.34 b$ & $10.13 a$ & $25.40 d$ & $5.32 \mathrm{a}$ & $5.03 b$ & $0.89 \mathrm{a}$ & $1978.65 f$ \\
\hline BRS-286 $\times$ CNPA-ITA-90 & $28.90 \mathrm{~b}$ & $83.65 b$ & $8.61 \mathrm{~b}$ & $27.36 \mathrm{c}$ & $5.58 \mathrm{a}$ & $4.47 \mathrm{C}$ & $0.87 \mathrm{~b}$ & $2419.77 d$ \\
\hline BRS-286 $\times$ CNPA-5M & $29.94 b$ & $84.36 \mathrm{a}$ & $7.20 \mathrm{C}$ & $28.86 b$ & $5.26 \mathrm{a}$ & $4.78 \mathrm{C}$ & $0.89 \mathrm{a}$ & $2620.32 b$ \\
\hline BRS-286 $\times$ CNPA-7MH & $29.86 b$ & $84.41 \mathrm{a}$ & $7.18 \mathrm{c}$ & $29.83 b$ & $4.61 \mathrm{~b}$ & $5.02 \mathrm{~b}$ & $0.89 \mathrm{a}$ & $2688.06 \mathrm{~b}$ \\
\hline BRS-286 × BRS-Seridó & $29.31 b$ & $84.30 \mathrm{a}$ & $7.41 \mathrm{C}$ & $30.20 \mathrm{~b}$ & $5.05 b$ & $5.20 \mathrm{a}$ & $0.89 \mathrm{a}$ & $2602.23 b$ \\
\hline FMT-701 × CNPA-ITA-90 & $29.48 b$ & $84.35 a$ & $7.66 \mathrm{c}$ & $29.71 b$ & $4.97 \mathrm{~b}$ & $4.47 \mathrm{C}$ & $0.87 b$ & $2694.74 b$ \\
\hline FMT-701 × CNPA-5M & $31.97 \mathrm{a}$ & $85.04 \mathrm{a}$ & $6.60 \mathrm{c}$ & $30.78 a$ & $4.84 b$ & $4.56 \mathrm{c}$ & $0.89 \mathrm{a}$ & $2953.34 \mathrm{a}$ \\
\hline FMT-701 × CNPA-7MH & $29.29 b$ & $83.59 \mathrm{~b}$ & $7.90 \mathrm{c}$ & $29.39 \mathrm{~b}$ & $4.70 \mathrm{~b}$ & $4.79 \mathrm{c}$ & $0.89 \mathrm{a}$ & $2571.85 \mathrm{c}$ \\
\hline FMT-701 × BRS-Seridó & $28.40 \mathrm{~b}$ & $83.89 \mathrm{~b}$ & $8.84 \mathrm{~b}$ & $28.86 \mathrm{~b}$ & $4.46 \mathrm{~b}$ & $5.24 \mathrm{a}$ & $0.90 \mathrm{a}$ & $2338.84 \mathrm{e}$ \\
\hline
\end{tabular}

Means followed by the same letter in the columns are from the same group and not different by the Scott-Knott's test (p $\leq 0.05$ ); UHM - Fiber length; UNF - Fiber uniformity; SFI - Short fiber index; STR - Strength; ELG - Elongation at break; MIC - Micronaire index; MAT - Maturity; CSP - Spinning index 
by the Scott-Knott test ( $\mathrm{p} \leq 0.05)$, allowing the identification of the most promising combinations.

According to Freire (2015), textile industries demands fiber with uniformity (UNF) greater than $83 \%$, low short fiber index (SFI), micronaire (MIC) between 3.5 and 5.0, length (UHM) above $30 \mathrm{~mm}$, strength (STR) between 31 and $34 \mathrm{gf} \mathrm{tex}^{-1}$, and spinning index (CSP) between 2000 and 2500.

Most hybrid combinations presented uniformity above that demanded by industries. The most significant combinations were FM-966 $\times$ CNPA-7MH (85.57\%) and FM-966 $\times$ BRSSeridó (85.99\%), highlighting the parent FM-966, present in both hybrid combinations. These are similar values to those found by Queiroz et al. (2017), who estimated GCA and SCA in cotton hybrids for fiber quality.

A low SFI denotes a low yarn breaking level and, consequently, high strength during the yarn manufacturing process (Cordão Sobrinho et al., 2015). According to Queiroz et al. (2017), low fiber strength is associated with the low synthesized carbohydrates and cellulose deposition in the fibers, which are hydrogen bridges responsible for connecting cellulose microfibers of the fiber primary and secondary layers. The hybrids FMT-701 $\times$ CNPA-5M (6.60\%) and FMT-705 $\times$ CNPA-5M (6.76\%) presented the lowest mean SFI. This result denotes the importance of the parent CNPA-5M for waterstress conditions.

Micronaire is a dimensionless trait that refers to fiber fineness, greatly affected by cellulose levels in the fiber secondary wall. This index estimates the amount of fibers that will make up the yarn cross section and its strength and regularity as a function of length (Pettigrew, 2004). A MIC lower than 3.5 indicates immature fibers and a MIC above 5.0 indicates very coarse fibers. The best hybrid combination for this trait was BRS-RUBI $\times$ CNPA-7MH (4.29). However, several hybrids had MIC within the ideal range, especially those of group c (Table 3). Similar MIC were found by Campbell et al. (2016), who estimated the genetic variation for agronomic and fiber quality traits using a partial diallel without the reciprocal and found significant additive effects on strength, length, and micronaire.

Most hybrids showed fiber length (UHM) above $30 \mathrm{~mm}$, especially the hybrids FM-966 $\times$ CNPA-5M $(31.17 \mathrm{~mm})$ and FMT-701 $\times$ CNPA-5M (31.97 mm). The mean UHM found were above that reported by Campbell et al. (2016), who estimated genetic variation using diallel analysis and found mean UHM of $28.70 \mathrm{~mm}$.
The expressive contribution of the genotype CNPA-5M is evident in both hybrid combinations, confirming that this genotype has a reasonable tolerance to semiarid environments, contributing to the maintenance of the trait pattern.

Elongation is the extension degree of the fibers before breaking when measuring strength (Freire, 2015). Studies report that water stress during flowering and fiber development stages affect elongation due to physiological mechanisms of the cell expansion, which affect fiber length (Pettigrew, 2004). The combinations FMT-705 $\times$ CNPA-5M (6.04\%), BRS-286 $\times$ CNPA-ITA-90 (5.58\%), and BRS-RUBI $\times$ CNPA-ITA-90 (5.53) had the highest elongation means. These results confirm those found by $\mathrm{Ng}$ et al. (2014).

The spinning index (CSP) is an indicator of yarn strength, which depends essentially on individual fibers. The ideal CSP based on the requirements of textile industries are above 2000 (Queiroz et al., 2017). Most hybrids presented CSP within the adequate range, with means above 2000 . The hybrids with the highest CSP were FMT-705 × CNPA-ITA-90 (2334), FMT-705 $\times$ CNPA-7MH (2384), BRS-RUBI $\times$ CNPA-5M (2332), and BRS-RUBI $\times$ CNPA-7MH (2007).

Most lines presented satisfactory fiber traits, even after 23 days of water stress. The hybrid FM-966 $\times$ CNPA-5M presented more desirable results for the traits, with lengths above $30 \mathrm{~mm}$. The diallel analysis for the parents and their $\mathrm{F}_{1}$ hybrids for fiber quality traits (Table 4) showed significant effect for GCA for all traits, except ELG for group I, and ELG and UHM for group II. However, no significant difference was found for SCA for any of the evaluated traits, indicating the predominance of additive genetic effects, as also found by Queiroz et al. (2017).

These results indicate that the GCA is enough to select promising crosses to obtain drought-tolerant lines, and to provide expressive genetic gains to cotton breeding programs, mainly for the development of cultivars for the Semiarid region of Brazil. The additive effects contributed more to UHM, STR, and CSP, indicating that the main fiber properties were controlled by additive genetic effects. Similar results were also reported by Tang \& Xiao (2014), Tang et al. (2016), and Queiroz et al. (2017).

Karademir \& Gencer (2010) evaluated the combining ability for agronomic and fiber quality traits of cotton and found that GCA effects were more expressive than SCA effects for most traits, indicating predominance of additivity of genes involved in the genetic control of these traits.

Table 4. Diallel analysis of cotton fiber traits between $\mathrm{F}_{1}$ cotton hybrids grown under water stress conditions

\begin{tabular}{|c|c|c|c|c|c|c|c|c|c|}
\hline \multirow{2}{*}{ SV } & \multirow{2}{*}{ DF } & \multicolumn{8}{|c|}{ Mean square } \\
\hline & & UHM & UNF & SFI & STR & ELG & MIC & MAT & CSP \\
\hline Genotype (G) & 19 & $15.74^{* *}$ & $6.14^{\star \star}$ & $8.04^{* \star}$ & $33.48^{\star \star}$ & $1.47^{\star \star}$ & $0.63^{\star *}$ & $0.0005^{\star *}$ & $495213.65^{* *}$ \\
\hline GCA - I & 4 & $50.54^{*}$ & $19.84^{*}$ & $25.78^{* *}$ & $115.19 * *$ & 3.78 & $0.68^{\star *}$ & $0.0010^{* *}$ & $1563804.14^{*}$ \\
\hline GCA - II & 3 & 21.04 & $5.93^{*}$ & $10.65^{*}$ & $33.47^{\star}$ & 1.96 & $2.08^{\star *}$ & $0.0022^{*}$ & $669691.23^{*}$ \\
\hline SCA & 12 & 2.82 & 1.63 & 1.49 & 6.26 & 0.57 & 0.25 & 0.0001 & 95396.29 \\
\hline Years (Y) & 1 & $43.38^{\star \star}$ & 0.001 & 0.22 & 2.34 & 1.24 & $2.85^{\star \star}$ & 0.0017 & 210899.52 \\
\hline$G \times Y$ & 19 & $2.48^{\star \star}$ & $1.80^{\star *}$ & 0.53 & $3.29 * *$ & $0.35^{\star \star}$ & $0.12^{\star \star}$ & 0.0001 & $91029.55^{\star \star}$ \\
\hline $\mathrm{GCA}-\mathrm{I} \times \mathrm{Y}$ & 4 & $4.40^{* *}$ & $2.71 * *$ & 0.29 & $4.56^{*}$ & $0.67^{* *}$ & 0.03 & 0.0001 & $123799.96^{* *}$ \\
\hline$G C A-\| \times Y$ & 3 & $3.50 * *$ & 0.64 & 0.59 & $3.71^{*}$ & 0.26 & 0.01 & 0.0001 & 42942.89 \\
\hline$S C A \times Y$ & 12 & $1.58^{\star \star}$ & $1.78^{*}$ & $0.60^{*}$ & $2.76^{\star}$ & $0.27^{\star}$ & $0.18^{\star \star}$ & 0.0001 & 92128.32 \\
\hline Error & 76 & 0.64 & 0.85 & 0.32 & 1.36 & 0.12 & 0.02 & 0.0001 & 30665.52 \\
\hline & & $(\mathrm{mm})$ & & & $\left(g f t e x^{-1}\right)$ & (\%) & & $(\%)$ & \\
\hline Means & & 28.78 & 84.13 & 7.97 & 28.60 & 5.01 & 4.85 & 0.88 & 2528.80 \\
\hline
\end{tabular}

${ }^{*}$ and ${ }^{* *}$ - Significance at $\mathrm{p} \leq 0.05$ and $\mathrm{p} \leq 0.01$, respectively; SV - Source of variation; DF - Degrees of freedom; UHM - Fiber length; UNF - Fiber uniformity; SFI - Short fiber index; STR - Strength; ELG - Elongation at break; MIC - Micronaire index; MAT - Maturity; CSP - Spinning index 
Table 5. GCA estimates (g) of cotton genotypes of group I (GI) and II (GII) under water stress conditions

\begin{tabular}{|c|c|c|c|c|c|c|c|c|}
\hline \multirow[b]{2}{*}{ Genotypes } & \multicolumn{8}{|c|}{ Evaluated traits } \\
\hline & $\begin{array}{l}\text { UHM } \\
(\mathrm{mm})\end{array}$ & UNF & SFI & $\begin{array}{c}\text { STR } \\
\left(\mathrm{gf} \text { te } x^{-1}\right)\end{array}$ & $\begin{array}{l}\text { ELG } \\
(\%)\end{array}$ & MIC & \multirow[t]{2}{*}{$\begin{array}{l}\text { MAT } \\
(\%)\end{array}$} & CSP \\
\hline & \multicolumn{7}{|c|}{ Group I } & \\
\hline 1. FMT-705 & -0.54 & 0.32 & -0.38 & 0.33 & 0.16 & $0.26^{*}$ & 0.01 & -34.80 \\
\hline 2. FM-966 & $1.13^{\star}$ & $1.00 *$ & $-0.83^{\star}$ & $1.88^{*}$ & $-0.51^{\star}$ & -0.02 & 0.01 & $278.42^{\star}$ \\
\hline 3. BRS-RUBI & $-2.30^{\star}$ & $-1.47^{\star}$ & $1.80^{\star}$ & $-3.76^{\star}$ & $0.50^{\star}$ & $-0.18^{\star}$ & -0.01 & $-408.30^{\star}$ \\
\hline 4. BRS-286 & 0.71 & 0.05 & -0.36 & 0.46 & 0.11 & 0.02 & 0.01 & 53.79 \\
\hline \multirow[t]{2}{*}{ 5. FMT-701 } & $1.00^{*}$ & 0.08 & -0.21 & $1.08^{*}$ & -0.27 & -0.08 & 0.01 & 110.89 \\
\hline & \multicolumn{8}{|c|}{ Group II } \\
\hline 6. CNPA-ITA-90 & -0.77 & -0.62 & 0.68 & $-1.46^{\star}$ & 0.21 & $-0.24^{\star}$ & -0.01 & -111.01 \\
\hline 7. CNPA-5M & $1.14^{\star}$ & 0.42 & -0.67 & $0.73^{\star}$ & 0.23 & -0.11 & -0.01 & $183.74^{\star}$ \\
\hline 8. CNPA-7MH & 0.07 & 0.14 & -0.27 & 0.81 & -0.23 & -0.01 & 0.01 & 59.12 \\
\hline 9. BRS-Seridó & -0.44 & 0.05 & 0.26 & -0.09 & -0.20 & $0.36^{*}$ & 0.01 & -131.86 \\
\hline
\end{tabular}

* - Significance at $\mathrm{p} \leq 0.05$; UHM - Fiber length; UNF - Fiber uniformity; SFI - Short fiber index; STR - Strength; ELG - Elongation at break; MIC - Micronaire index; MAT - Maturity; CSP - Spinning index

The GCA-I $\times$ Y interaction was significant for most traits, and GCA-II $\times$ Y interaction was significant for UHM and STR. The SCA $\times$ Y interaction was not significant for MAT and CSP, indicating variations in GCA-I and GCA-II of the parents and SCA of the hybrids in both years evaluated.

Considering the results of the diallel analysis, only the GCA effects of the parents involved in the diallel cross were estimated (Table 5). GCA estimates for the genotypes of Groups I and II showed significant genetic contributions from parents to improve cotton fiber traits, with potential to generate new genotypes more tolerant to water stress and better adapted to semiarid conditions. The parents FM-966 (GI) and CNPA-5M (GII) contributed to the increase in UHM, STR, and CSP, and to the reduction in short fiber index (SFI). However, the parent BRS-RUBI had the worst performance; this was expected, because this cultivar presents fiber quality below the market requirements.

These findings indicate that the genetic basis of the parents used for the diallel cross is important to increase the frequency of favorable alleles for tolerance to water stress for the studied traits, resulting in superior lines and expressive genetic gains. According to Cruz et al. (2012), the best hybrid combination to be selected in a diallel analysis should have a high SCA, with at least one parent having a high GCA.

\section{Conclusions}

1. Additive effects are the most important for the control of fiber traits.

2. The exploration of hybrid combination between the parents FM-966 (GI) and CNPA-5M (GII) should be focused because of their potential to generate superior lines for fiber quality in environments subjected to water stress.

3. The parents FM-966 (GI) and CNPA-5M (GII) contribute to fit the genetic plasticity of cotton plants to water stress conditions during the beginning of the reproductive stage, which may generate significant genetic gains in the selection process.

\section{Literature Cited}

ABRAPA - Associação Brasileira dos Produtores de Algodão. 2018. Available on: <http://www.abrapa.com.br/estatisticas/paginas/ algodao-no-brasil.aspx>. Accessed on: Nov. 2018.
Bezerra, J. R. C.; Azevedo, P. V.; Silva, B. B. da; Dias, J. M. Evapotranspiração e coeficiente de cultivo do algodoeiro BRS200 Marron, irrigado. Revista Brasileira de Engenharia Agrícola e Ambiental, v.14, p.625-632, 2010. https://doi.org/10.1590/ S1415-43662010000600009

Campbell, B. T.; Greene, J.; Wu, J.; Jones, D. C. Genetic variation for agronomic and fiber quality traits in population derived from high quality cotton germplasm. Crop Science, v.56, p.1689-1697, 2016. https://doi.org/10.2135/cropsci2015.10.0657

Carvalho, L. P. de; Salgado, C. C.; Farias, F. J. F.; Carneiro, V. Q. Estabilidade e adaptabilidade de genótipos de algodão de fibra colorida quanto aos caracteres de fibra. Ciência Rural, v.45, p.598605, 2015. https://doi.org/10.1590/0103-8478cr2013023

Cia, E.; Fuzatto, M. G.; Almeida, W. P.; Kondo, J. I.; Ito, M. F.; Dias, F. L. F. Reaction of cotton genotypes to Alternaria leaf spot. Summa Phytopathologica, v.40, p.81-83, 2014. https://doi.org/10.1590/ S0100-54052014000100013

Cordão Sobrinho, F. P.; Guerra, H. O.; Araújo, W. P.; Pereira, J. R.; Zonta, J. H.; Bezerra, J. R. Fiber quality of upland cotton under different irrigation depths. Revista Brasileira de Engenharia Agrícola e Ambiental, v.19, p.1057-1063, 2015. https://doi. org/10.1590/1807-1929/agriambi.v19n11p1057-1063

Coutinho, C. R.; Andrade, J. A. S.; Pegoraro, R. F. Produtividade e qualidade de fibra de cultivares de algodoeiro (Gossypium hirsutum L.) na região do semiárido mineiro. Essentia, v.16, p.62-82, 2015.

Cruz, C. D. Genes Software: Estendido e integrado com o R, Matlab e Selegen. Acta Scientiarum, v.38, p.547-552, 2016. https://doi. org/10.4025/actasciagron.v38i3.32629

Cruz, C. D.; Regazzi, A.; Carneiro, P. C. S. Análise dialélica. In: Cruz, C. D. (ed.). Modelos biométricos aplicados ao melhoramento genético. Viçosa: Editora UFV, 2012. Cap.7, p.236-367.

Dabbert, T. A.; Gore, M. A. Challenges and perspectives on improving heat and drought stress resilience in cotton. Journal of Cotton Science, v.18, p.393-409, 2014.

Freire, E. C. Fatores que afetam a qualidade das fibras. In: Freire, E. C. (ed.). Algodão no cerrado do Brasil. Brasília: Positiva, 2015. Cap.6, p.653-750.

Freire, E. C.; Medeiros, J. da C.; Silva, C. A. D. da; Azevedo, D. M. P. de; Andrade, F. P. de; Vieira, D. J. Cultura dos algodoeiros mocó precoce e Algodão 7MH. Campina Grande: Embrapa Algodão, 1999. 65p. Circular Técnica, 28 
Geraldi, I. O.; Miranda-Filho, J. B. de. Adapted models for the analysis of combining ability of varieties in partial diallel crosses. Brazilian Journal of Genetics, v.11, p.419-430, 1988.

Griffing, B. Concept of general and specific ability in relation to diallel crossing systems. Australian Journal of Biological Sciences, v.9, p.462-469, 1956. https://doi.org/10.1071/BI9560463

Imran, M.; Shakeel, A.; Azhar, F. M.; Farooq, J.; Saleem, M. F.; Saeed, A.; Nazeer, W.; Riaz, M.; Naeem, M. E.; Javaid, A. Combining ability analysis for within-boll yield components in upland cotton (Gossypium hirsutum L.). Genetics and Molecular Research, v.11, p.2790-2800, 2012. https://doi.org/10.4238/2012.August.24.4

Karademir, E.; Gencer, O. Combining ability and heterosis for yield and fiber quality properties in cotton (Gossypium hirsutum L.) obtained by half diallel mating design. Notulae Botanicae Horti Agrobotanici Cluj-Napoca, v.38, p.222-227, 2010.

Kothari, N.; Campbell, T. B.; Dever, J. K.; Hinze, L. L. Combining ability and performance of cotton germplasm with diverse seed oil content. Crop Science, v.56, p.19-29, 2016. https://doi. org/10.2135/cropsci2015.03.0166

Kumar, K.; Ashokkumar, K.; Ravikesavan, R. Genetic effects of combining ability studies for yield and fiber quality traits in diallel crosses of upland cotton (Gossypium hirsutum L.). African Journal Biotechnology, v.13, p.119-126, 2014. https://doi.org/10.5897/ AJB2013.13079

Ng, E. H.; Smith, C. W.; Hequet, E.; Hague, S.; Dever, J. Diallel analysis of fiber quality traits with an emphasis on elongation in upland cotton. Crop Science, v.54, p.514-519, 2014. https://doi. org/10.2135/cropsci2013.06.0414

Pettigrew, W. T. Moisture deficit effects on cotton lint yield, yield components, and boll distribution. Agronomy Journal, v.96, p.377383, 2004. https://doi.org/10.2134/agronj2004.3770

Queiroz, D. R.; Farias, F. J. C.; Cavalcanti, J. J. V.; Carvalho, L. P.; Neder, D. G.; Souza, L. S. S.; Farias, F. C.; Teodoro, P. E. Diallel analysis for technological traits in upland cotton. Genetics and Molecular Research, v.16, p.2-8, 2017. https://doi.org/10.4238/gmr16039727
Rodrigues, J. I da S.; Carvalho, L. P. de; Farias, F. J. C. Influence of genotype versus environment interaction on improving upland cotton yield. Amazonian Journal of Agricultural and Environmental Sciences, v.60, p.241-246, 2018. https://doi. org/10.4322/rca.2451

Scott, A. J.; Knott, M. A cluster analysis method for grouping means in the analysis of variance. Biometrics, v.30, p.507-512, 1974. https://doi.org/10.2307/2529204

Tang, F.; Cheng, W.; Xiao, W. Genetic Effects of high fibre strength breeding lines in crosses with transgenic bt cotton cultivars (Gossypium hirsutum L.). Czech Journal of Genetics and Plant Breeding, v.52, p.14-20, 2016. https://doi.org/10.17221/116/2015CJGPB

Tang, F; Xiao, W. Genetic association of within-boll yield components and boll morphological traits with fibre properties in upland cotton (Gossypium hirsutum L.). Plant Breeding, v.133, p.521-529, 2014. https://doi.org/10.1111/pbr.12176

Vasconcelos, U. A. A.; Cavalcanti, J. J. V.; Farias, F. J. C.; Vasconcelos, W. S.; Santos R. C. dos. Diallel analysis in cotton (Gossypium hirsutum L.) for water stress tolerance. Crop Breeding and Applied Biotechonology, v.18, p.24-30, 2018. https://doi.org/10.1590/198470332018v18n1a4

Vidal Neto, F. das C.; Freire, E. C. de. Melhoramento genético do algodoeiro. In: Vidal Neto, F. das C.; Cavalcanti, J. J. V. (eds.). Melhoramento genético de plantas no Nordeste. Fortaleza: Embrapa Agroindústria Tropical, 2013. Cap. 2, p.49-83.

Zeng, L.; Pettigrew, W. T. Combining ability, heritability, and genotypic correlations for lint yield and fiber quality of upland cotton in delayed planting. Field Crops Research, v.171, p.176-183, 2015. https://doi.org/10.1016/j.fcr.2014.10.004

Zonta, J. H.; Brandão, Z. N.; Sofiatti, V.; Bezerra, J. R.; Medeiros, J. da C. Irrigation and nitrogen effects on seed cotton yield, water productivity and yield response factor in semi-arid environment. Australian Journal of Crop Science, v.10, p.118-126, 2016. 